\title{
Mass balance of 'Glaciar Bahía del Diablo', Vega Island, Antarctic Peninsula
}

\author{
Pedro SKVARCA, Hernán DE ANGELIS, Evgeniy ERMOLIN \\ Instituto Antártico Argentino, Cerrito 1248, C1010AAZ Buenos Aires, Argentina \\ E-mail: glacio@dna.gov.ar
}

\begin{abstract}
Given the pronounced atmospheric warming recorded in recent decades on the Antarctic Peninsula (AP), knowledge of glacier mass balance in this region is especially important for assessing the impact of climatic warming on ice masses. 'Glaciar Bahía del Diablo' (GBD) on Vega Island, northeastern $\mathrm{AP}$, is a glacier that terminates on land, so its mass balance is directly linked to climate. GBD is a polythermal outlet glacier, $14.3 \mathrm{~km}^{2}$ in area with an accumulation-area ratio of 0.39 . Increased ablation rates and glacier thinning motivated us to select GBD as a test site for mass-balance studies within the region. Calculations based on the stratigraphic annual method yielded a mean annual loss of $0.32 \mathrm{~m}$ w.e. $\mathrm{a}^{-1}$ for the annual net mass balance $\left(b_{n}\right)$ between 1999 and 2003. A strong correlation was observed between $b_{\mathbf{n}}$ and mean summer temperatures, confirming that GBD is highly sensitive to climate. The study of GBD aims at establishing a suitable reference database for ice-climate studies in a region of dramatic changes in Antarctica.
\end{abstract}

\section{INTRODUCTION}

The Antarctic Peninsula (AP) is the only region of Antarctica where a pronounced atmospheric warming of $2.5^{\circ} \mathrm{C}$ has been detected since 1945 (King, 1994). Coincident with this climatic amelioration, the extent of ice cover on the AP has experienced dramatic changes in recent years. The regional climatic warming has induced the disintegration of ice shelves around the AP (Rott and others, 1996; Vaughan and Doake, 1996; Skvarca and others, 1999; Scambos and others, 2000). In addition, an increased general glacier retreat has been documented since 1975 on the northeastern AP (Skvarca and others, 1995; De Angelis and Skvarca, 2003). Skvarca and others (1998) have described clear evidence of climatic warming on the northeastern AP, as well as its impact on ice masses within this region (Skvarca and De Angelis, 2003).

Due to the high sensitivity of polar regions to climate change, monitoring the mass balance of polar and subpolar ice masses, among other environmental variables, is important (Weller, 1998). Long-term studies on Arctic glaciers, excluding the Greenland ice sheet, have shown a predominantly negative mass-balance trend during the last 60 years (Dowdeswell and others, 1997). Mass-balance data on the AP are limited due to difficult access and expensive logistics. Earlier work was confined mainly to the northern and southwestern regions of the AP. Mass-balance conditions were analyzed between 1968 and 1974 at three different localities on the South Shetland Islands (Orheim and Govorukha, 1982). However, the most comprehensive and detailed studies, including energy balance, were carried out from 1969 to 1974 as a contribution to the International Hydrological Decade 1965-74, on Spartan Glacier (SG), Alexander Island, southwestern AP $\left(71.05^{\circ} \mathrm{S}, 68.33^{\circ} \mathrm{W}\right)$ (Jamieson and Wager, 1983; Wager and Jamieson, 1983).

The lack of mass-balance data, increased regional atmospheric warming and detection of significant changes prompted a mass-balance program on Vega Island, northeastern AP, in the austral summer of 1998/99. This is one of the few sites in the AP where glaciers terminate on land, so the mass balance of these glaciers is directly related to climate. The objective of the mass-balance program on Vega Island is to establish a benchmark in the region of drastic changes induced by atmospheric warming. The selected glacier, which we informally call 'Glaciar Bahía del Diablo' (GBD; $63^{\circ} 49^{\prime} \mathrm{S} ; 57^{\circ} 26^{\prime} \mathrm{W}$; Fig. 1 ), has an area of $14.3 \mathrm{~km}^{2}$ (measured in early 2000) and an accumulation-area ratio (AAR) of 0.39 (averaged over the period 1999-2003); this outlet glacier drains an ice cap from 630 to $75 \mathrm{~m}$ a.s.l. The accumulation area is oriented northeastwards and the ablation area eastwards (Fig. 2). GBD is polythermal, with its snout overriding an ice-cored thrust moraine on a periglacial plain of continuous permafrost (Ermolin and others, 2002). An automatic weather station was installed during the 1998/99 field campaign about $700 \mathrm{~m}$ from the glacier front (VIAWS in Fig. 2), and has been running continuously since 17 February 1999. The mean annual air temperature (MAAT), averaged over the 3 year period $2000-02$, is $-5.5^{\circ} \mathrm{C}$. The present work deals with mass-balance measurements carried out on GBD from 1999 to 2003. Due to changes in data processing, the values for annual balance reported here differ slightly from, and replace, those presented in Skvarca and De Angelis (2003). Glacier thinning rates covering the period 1982-2003 are also analyzed.

\section{PREVIOUS WORK}

Basic glaciological studies on GBD began during the austral summer of 1981/82. The early work established a local triangulation network, and measured ice-flow velocity, ablation rates and glacier surface elevation change. However, research in the early 1980s was confined to the lower part of the GBD ablation area and the surrounding periglacial plain. Measurements indicated almost no change in glacier surface height from 1982 to 1985, suggesting that the glacier was close to equilibrium. However, the 1998/99 summer survey revealed that glacier surface height fell on average $12.6 \mathrm{~m}$ from 1985 to 1998 (13 years), yielding an average annual thinning rate of $1.0 \mathrm{~m} \mathrm{a}^{-1}$ (Skvarca and De Angelis, 2003). This surface lowering resulted from averaging 23 surveyed points distributed over the $2.2 \mathrm{~km}$ long 


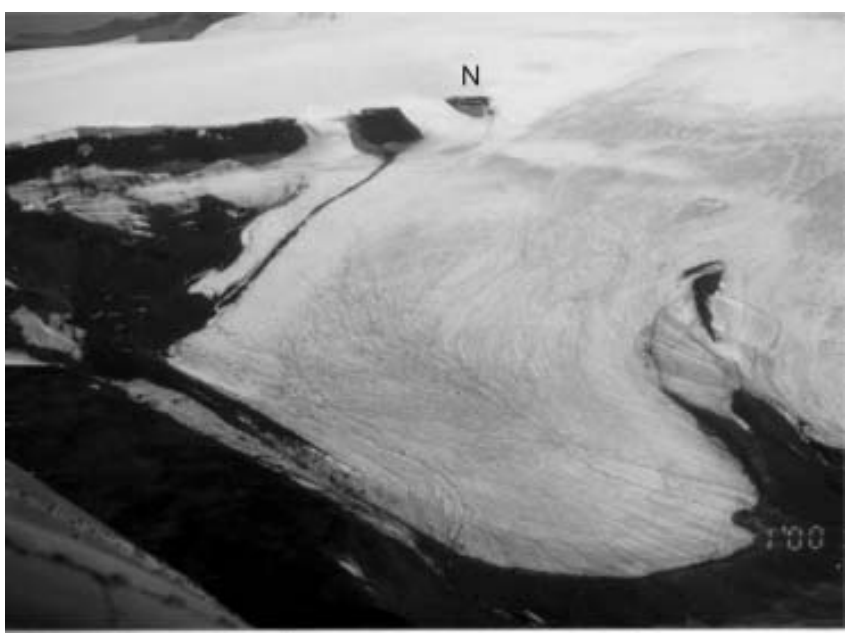

Fig. 1. Oblique aerial photograph of GBD, 27 January 2000. Note the abundance of supraglacial meltwater streams resulting from the unusually warm summer 1999/2000, as well as the complex pattern of accumulation on the upper part of GBD (top of photograph), visible also on the Landsat image of Figure 2. N: nunatak.

lower part of the glacier ablation area. From 1998 to 1999 the thinning rate increased to $1.4 \mathrm{~m} \mathrm{a}^{-1}$. Regional warming is believed to be a main cause for this enhanced thinning. The summer of 1998/99 was among the warmest recorded in the region, as revealed by the mean summer air-temperature (MSAT; December-February) records of Esperanza and Marambio stations (Skvarca and De Angelis, 2003), located about $50 \mathrm{~km}$ to the north and south, respectively. Both records show a strong correlation in MSAT over the last three decades $(R=0.93)$. The last four summers of temperature data suggest a much stronger correlation $(R=0.99)$ for Esperanza-VIAWS and Marambio-VIAWS stations.

\section{MASS-BALANCE METHODS}

\section{Field method and work}

For GBD we have applied a simplified version of the combined stratigraphic-annual-mass-balance method described in Mayo and others (1972). An annual (fixed-date) system, which considers each glaciological (balance) year from 1 March to 28/29 February of the following calendar year, has been adopted and used. These dates are climatically significant because they roughly coincide with the end of the summer season on the northeastern AP. The application of this method allowed us to determine the annual net balance $b_{\mathrm{n}}$, regardless of the maximum and minimum seasonal balances. This method is convenient since fieldwork was restricted to one visit per year, due to logistic constraints.

Direct surface-based methods have been used to measure the mass balance of GBD (Østrem and Brugman, 1991). A network of 36-38 stakes (depending on the year) were distributed over the glacier (Fig. 2), representing a fairly high density of around 2.5 stakes $\mathrm{km}^{-2}$. The stake positions were determined each year by means of differential global positioning system (DGPS). We used a Trimble ${ }^{\circledR}$ Pro XL, 8-channel, single-frequency receiver as rover station, and a Trimble $^{\circledR}$ 4600LS, 12-channel, single-frequency receiver as base station. Raw positions with coarse acquisition (C-A) code, L1 frequency and phase information were corrected using Trimble ${ }^{\circledR}$ Pathfinder Office software with Centimeter

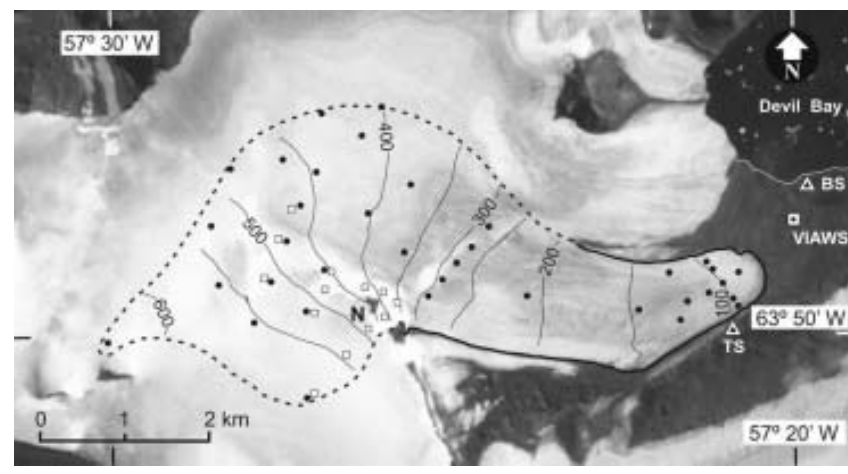

Fig. 2. Topographic map of GBD, superimposed over a section of Landsat 7 ETM+ image of 21 February 2000. Contour lines are in meters. Circles indicate positions of stakes, and squares the locations of snow pits. The glacier drainage area is delineated by a dashed line. N: nunatak; TS: triangulation station; VIAWS: Vega Island automatic weather station; BS: location of GPS base station.

Processor ${ }^{\circledR}$ enhancing capability. This combination provides horizontal and vertical precisions in the order of $0.10 \mathrm{~m}$, for baselines shorter than $8 \mathrm{~km}$. Routine mass-balance work consisted of measuring stake heights, snow stratigraphy, as well as the extent and thickness of superimposed ice. The superimposed ice was identified by its whitish color, saturation of trapped air and the fine-grained structure of ice layers parallel to the glacier surface. Snow-firn thickness and densities were measured in several snow pits distributed over the glacier accumulation area as shown in Figure 2. Each year the measurements were made at approximately the same locations. Snow-density profiles were measured in each snow pit to reduce the uncertainties arising from extrapolation of the snow-density values to areas without measurements. Glacier-ice and superimposed-ice densities were assumed as 900 and $870 \mathrm{~kg} \mathrm{~m}^{-3}$, respectively. In addition, snow probing was performed at regular intervals along several profiles between the stakes, to account for variations in snow accumulation. We used a standard snow probe which has a centimeter scale, and probing positions were taken from DGPS readings. Because of a lack of natural markers such as dust layers, the previous summer surfaces in the accumulation area of GBD were usually detected by the presence of distinct ice horizons and/or by the use of artificial powder-dye markers. Powder dye was spread over snow areas of about $2-3 \mathrm{~m}^{2}$ at selected places over the glacier at the end of the ablation season, and their positions were relocated with DGPS. During the following season the accumulated snow could be easily assessed by measuring the snow depth to the dyed layer.

The topographic map of GBD (shown in Figure 2 with $50 \mathrm{~m}$ contour lines) was produced with the aid of kinematic DGPS, using the receivers indicated earlier. The antenna of the rover instrument was mounted on a snowmobile following a grid spacing of $<100 \mathrm{~m}$. Positions were recorded at $1 \mathrm{~s}$ time intervals at both rover and base GPS receivers, with horizontal accuracy better than $0.20 \mathrm{~m}$ using carrierphase processing. All GPS surveys were referred to a single reference base station (BS) located near the Devil Bay coastline (see Fig. 2), tied to a first-order geodetic station on Seymour (Marambio) Island. In the past, ocean tide measurements were carried out at BS (Instituto Antártico Argentino, unpublished data), allowing us to know the local geoid-ellipsoid height difference. 
The height coordinate was controlled at each pole, where an accurate altitude above the World Geodetic System 1984 (WGS84) ellipsoid was calculated, referred to mean sealevel by means of static DGPS measurements. The overall uncertainty in post-processed height determinations is $<0.10 \mathrm{~m}$. All data acquired by means of DGPS surveys were integrated on a digital elevation model (DEM) with a grid size of $50 \mathrm{~m}$. The use of a grid size smaller than the survey spacing is justified by the fact that it improves the areal determinations without degrading the quality of the map (Jansson, 1999). The contours were automatically drawn by applying a minimum curvature algorithm. Finally, the ice divide and the drainage area of GBD was delineated using the surface contours in combination with a section of Landsat Enhanced Thematic Mapper Plus (ETM+) image acquired on 21 February 2000. The resulting drainage area derived for GBD in early 2000 is $14.3 \mathrm{~km}^{2}$.

The method for detecting changes in glacier surface elevation is based on repeated topographic measurements of the same points at different time intervals. Surveys over GBD were made from a triangulation station fixed on rock (TS in Fig. 2), relocating each time around the end of the summer season the same 23 points over the glacier by means of a theodolite and electronic distance meter. The reflector was positioned at each point within about $20 \mathrm{~cm}$ in horizontal coordinates, by fixing the corresponding azimuth angle and distance. The precision of height coordinates is estimated as $\pm 2.5 \mathrm{~cm}$, depending on the distance and instruments used.

\section{Data analysis}

The information acquired in the field was compiled in a spreadsheet. In certain cases, minor corrections were applied to account for late snowfalls or extra ablation, when measurements were carried out before or after the end of the balance year. In such cases, the corrections were based on the temperature records available from VIAWS. To calculate of the net balance along the glacier, we applied a simplified version of the procedure described in Jansson (1999), using a Geographical Information System (GIS). We determined $b_{\mathrm{n}}$ at each measurement point, resulting in text tables including positions and annual balances, which usually contained more than 70 mass-balance points for each balance year. Using these data as input and applying minimum curvature interpolation, we resampled the field data on a regular $50 \mathrm{~m} \times 50 \mathrm{~m}$ grid, obtaining the net balance maps for each balance year (Fig. 3). The use of a grid size smaller than the real field sampling distance does not improve the data quality but increases the accuracy of the automated area calculation, because integration is performed with smaller elements (Jansson, 1999). The grid elements falling outside the glacier boundaries were eliminated by using an appropriate outline mask. The net mass balance for each year was obtained by calculating the total volume of the grid divided by the total glacier surface. To determine the average variation of $b_{\mathrm{n}}$ vs altitude (Fig. 4), we used a topographic map constructed with a similar grid size, and extracted the gridded balances and altitudes.

Estimation of errors in mass-balance measurements and calculations is not a simple task (Østrem and Brugman, 1991; Cogley, 1999; Jansson, 1999). Though great care was taken in field measurements, these are inevitably affected by large errors. Cogley and others (1996) concluded that errors in fieldwork are of the same order as errors in individual stake readings, and can eventually reach $0.25 \mathrm{~m}$ w.e.
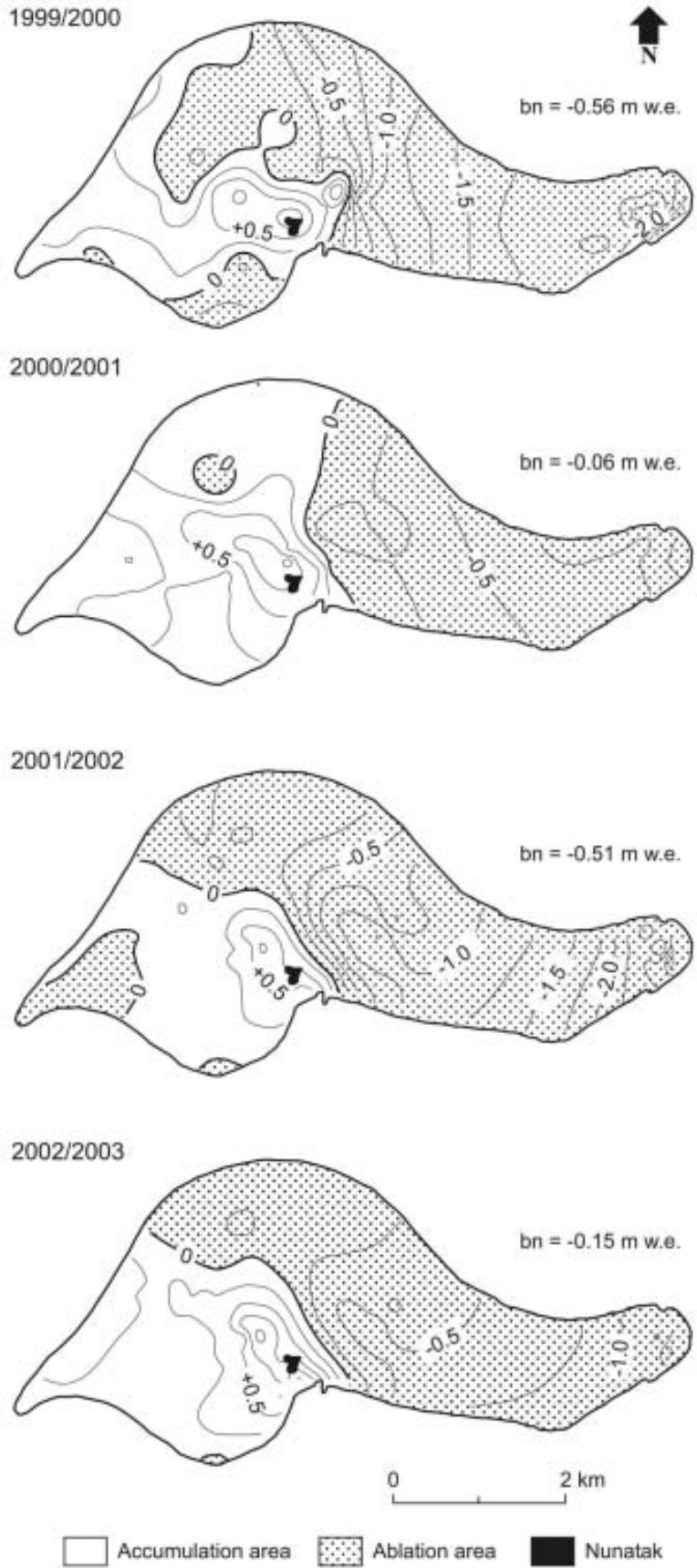

Fig. 3. Net annual balance maps for balance years 1999/2000, 2000/01, 2001/02 and 2002/03. Isolines indicate net balance, in $\mathrm{m}$ w.e.; zero is the equilibrium line. The ablation area is shown in dots.

However, the errors in both stake readings and snow probing are usually within 0.05 and $0.01 \mathrm{~m}$, and the propagation of these errors to final results is negligible (personal communication from P. Jansson, 2004). The errors in computation procedures can be identified by applying objective data processing. In order to estimate the computation errors of our mass-balance maps, we determined the residuals, i.e. the difference between measured and interpolated values for every year. We found in our maps an average residual of $0.02 \mathrm{~m}$ w.e., with a mean standard deviation of $0.08 \mathrm{~m}$ w.e. This estimate agrees well with the 


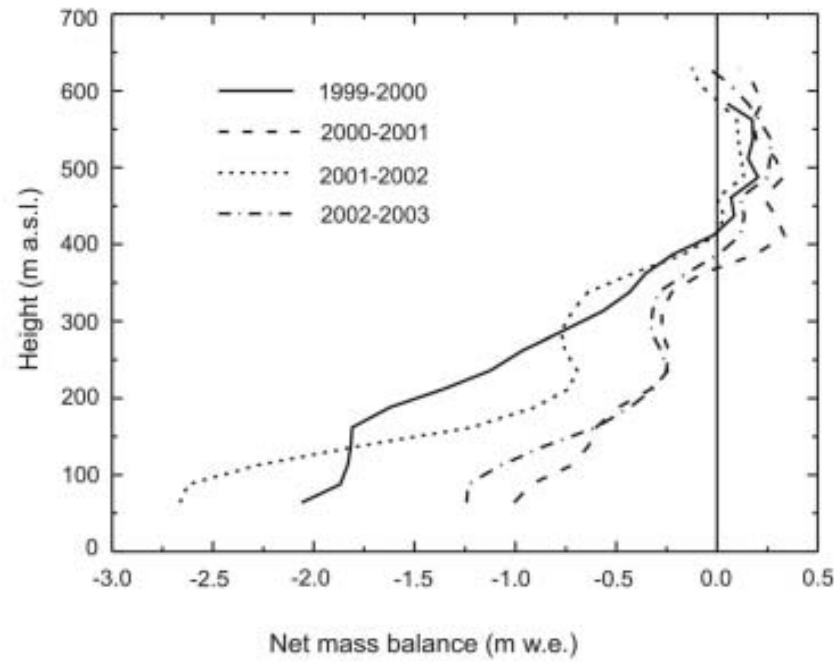

Fig. 4. Graph showing net balance $b_{\mathrm{n}}$ vs altitude, 1999-2003.

estimated error of about $0.1 \mathrm{~m}$ given by Jansson (1999), considering both observational and computation problems.

\section{RESULTS}

The net mass-balance maps are shown in Figure 3. The calculations yielded a net mass balance $\left(b_{\mathrm{n}}\right)$ of $-0.56 \mathrm{~m}$ w.e. for 1999/2000, -0.06 m w.e. for 2000/01, -0.51 m w.e. for 2001/02 and $-0.15 \mathrm{~m}$ w.e. for 2002/03. The mass balance of GBD in the past 4 years is negative, with a mean of $-0.32 \mathrm{~m}$ w.e. The mean error of our results, as estimated from the interpolated residuals, is $0.08 \mathrm{~m}$ w.e. The mass loss was largest in 1999/2000 and 2001/02, corresponding to the two warmest summers during the 4 year period. In addition to mass-balance measurements, the topographic surveys of surface elevation over the lower parts of the GBD tongue (100-250 ma.s.l.) yielded thinning rates of $1.6 \mathrm{ma}^{-1}$ for $1999 / 2000,0.4 \mathrm{~m} \mathrm{a}^{-1}$ for $2000 / 01$ and an average of $1.4 \mathrm{~m} \mathrm{a}^{-1}$ for the period 2001-03.

The results of balance years 1999/2000 and 2000/01 obtained in the present study $(-0.56$. and -0.06 mw.e., respectively) differ slightly, with -0.53 and -0.05 mw.e. reported by Skvarca and De Angelis (2003), because different computation procedures were used in each case. Formerly, these two balance years were calculated by using the classical manual mapping procedure rather than the automated method applied in this work. Although previous results are within error estimates, we consider the new values more coherent since a rational and more consistent procedure was applied throughout the years of mass-budget coverage.

The altitudinal variation of mass balance (Fig. 4) shows a zero net balance at about $400 \mathrm{~m}$ a.s.l. in both warmest years (1999/2000, 2001/02) of the observational period, which is at least $20 \mathrm{~m}$ higher than in the other two balance years, indicating that GBD mass balance is very sensitive to summer ablation. The correlation between the annual net mass balance $\left(b_{\mathrm{n}}\right)$ and mean summer air temperature measured at VIAWS is shown in Figure 5.

\section{DISCUSSION}

Four years of net mass-balance data from GBD reveal a strong response to the regional variability in summer air temperature. The balance years of GBD which include the two very warm summers of $1999 / 2000\left(\right.$ MSAT: $\left.+1.8^{\circ} \mathrm{C}\right)$ and

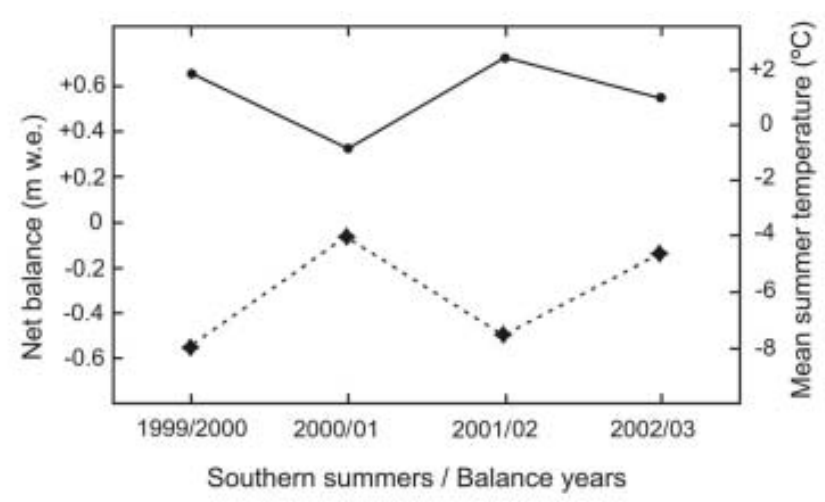

Fig. 5. Mean summer air temperature at VIAWS and annual net balance $\left(b_{n}\right)$ during the period of mass-balance analysis.

2001/02 (MSAT: $+2.4^{\circ} \mathrm{C}$ ) show a particularly complex accumulation pattern of high spatial variability over the upper parts of the glacier (Fig. 3). The highest net accumulation was measured on the lee side of the cliffs and steep slopes at about $350 \mathrm{ma.s.l}$., in the vicinity of nunatak $\mathrm{N}$ (Figs 1 and 2). Large ablation areas extended to the highest parts of GBD around $600 \mathrm{~m}$ a.s.l. during the 1999/2000 and 2001/02 summers, which were among the five warmest in the last three decades according to records of the northeastern AP (Skvarca and De Angelis, 2003). At the end of these two summer seasons the accumulation area exhibited zones of snow accumulation and ablation, separated by widespread zones of superimposed ice, as can be seen in Figures 1 and 2, and reflected on mass-balance maps (Fig. 3), indicating the difficulty of defining the equilibrium line in most balance years. Similar conditions were reported for SG, which exhibited a number of accumulation areas instead of a well-defined equilibrium line. SG provides the only other detailed record of mass balance on the $\mathrm{AP}$, although from a maritime climatic regime. This small valleytype glacier of $6.3 \mathrm{~km}^{2}$ had a negative mean mass balance of $-0.27 \mathrm{~m}$ w.e. $\mathrm{a}^{-1}$ over the period 1970-74 (Wager and Jamieson, 1983). This value is very similar to the $-0.32 \mathrm{~m}$ w.e. $\mathrm{a}^{-1}$ for GBD, resulting from our averaged mass-balance measurements between 1999 and 2003. However, the range of interannual variability in mass balance is much larger at GBD $\left(-0.06\right.$ to $-0.56 \mathrm{~m}$ w.e. $\left.\mathrm{a}^{-1}\right)$ than at SG $\left(-0.22\right.$ to $-0.35 \mathrm{~m}$ w.e. $\left.\mathrm{a}^{-1}\right)$.

The thinning rates averaged over the lower part of GBD surveyed during the period of mass balance are closely related to positive degree-day (PDD) sums. Figure 6 shows monthly PDD sums (in degree-days) derived from VIAWS during the period of mass-balance surveys. In 1999/2000 the thinning rate increased considerably to $1.6 \mathrm{~m} \mathrm{a}^{-1}$, from $1.0 \mathrm{~m} \mathrm{a}^{-1}$ in $1985-98$, due to a very warm summer with a PDD of 381 degree-days. During the balance year 2000/01, MSAT was low $\left(-0.8^{\circ} \mathrm{C}\right)$ ( 140 degree-days), and the thinning rate sharply decreased to $0.4 \mathrm{~m} \mathrm{a}^{-1}$. The rate of lowering averaged over 2001-03 increased to $1.4 \mathrm{~m} \mathrm{a}^{-1}$ because of very high summer temperatures in 2001/02, the warmest summer recorded in the northeastern AP region since 1903 (Skvarca and De Angelis, 2003). The PDD sums for balance years 2001/02 and 2002/03 were 334 and 160 degree-days, respectively (Fig. 6). It can be argued that the observed response of GBD could also be a result of changes in its internal polythermal condition, since it is known that the thermal state of subpolar ice masses can be severely affected 


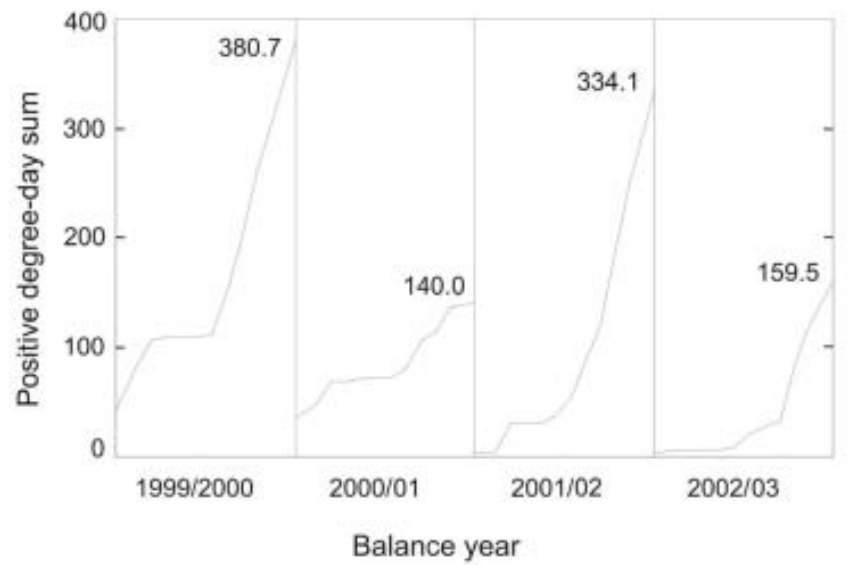

Fig. 6. Cumulative positive degree-day (PDD) during balance years as derived from VIAWS.

by climate change (Blatter and Hutter, 1991). However, the lack of sufficient englacial temperature observations prevents us from further assessing the thermodynamics.

An indication that ice is also thinning on the southwestern AP is given by surface lowering detected between 1989 and 1997 on the $\sim 600 \mathrm{~m}$ long ice ramp at Rothera Point (RP; $67.57^{\circ} \mathrm{S}, 68.12^{\circ} \mathrm{W}$ ) in Marguerite Bay, associated with long term-increase in air temperature and decrease in surface mass balance (Smith and others, 1998). Although MAATs at both sites are very similar (RP: $-6.4^{\circ} \mathrm{C}$; GBD: $-5.5^{\circ} \mathrm{C}$ ), the mean thinning rate of $0.32 \mathrm{~m} \mathrm{a}^{-1}$ reported for RP ice ramp is lower than the $1.0 \mathrm{~m} \mathrm{a}^{-1}$ surface lowering of GBD averaged over a larger area and longer period (1985-98). This might be explained by different climatic regimes, continental and maritime, affecting the eastern and western AP, respectively (Schwerdtfeger, 1984). Detection of ice thinning and negative mass balances of ice masses on both sides of the AP are a clear indicator of the general warming trend affecting this region.

\section{CONCLUSIONS}

The results of direct mass-balance measurements clearly indicate that GBD was wasting mass from 1999 to 2003, at a mean rate of $0.32 \mathrm{~m}$ w.e. $\mathrm{a}^{-1}$. However, the data on glacier thinning rates available since 1985 and the high correlation between VIAWS and nearby Esperanza weather station, which shows MSATs at or above $0^{\circ} \mathrm{C}$ from 1980 to the present, suggest that negative balances extended back at least to the mid-1980s. Therefore, GBD probably has had a negative mass budget over the last two decades due to the increasing warming trend. This is supported by measurements of glacier thinning since 1985 .

\section{ACKNOWLEDGEMENTS}

The authors express their thanks to T. Toconás, J. C. Quinteros and D. Lepe for their efficient support during field campaigns. Discussions with P. Holmlund and P. Jansson, as well as comments made by G. Casassa, A. Fountain and M. Hoelzle, helped greatly to improve the manuscript. This work is a contribution to the project 'Interacción HieloClima y Dinámica de Glaciares en Península Antártica y Patagonia Austral', funded by Dirección Nacional del Antártico-Instituto Antártico Argentino.

\section{REFERENCES}

Blatter, H. and K. Hutter. 1991. Polythermal conditions in Arctic glaciers. J. Glaciol., 37(126), 261-269.

Cogley, J. G. 1999. Effective sample size for glacier mass balance. Geogr. Ann., 81A(4), 497-507.

Cogley, J. G., W. P. Adams, M. A. Ecclestone, F. Jung-Rothenhäusler and C.S.L. Ommanney. 1996. Mass balance of White Glacier, Axel Heiberg Island, N.W.T., Canada, 1960-1991. J. Glaciol., 42(142), 548-563.

De Angelis, H. and P. Skvarca. 2003. Glacier surge after ice shelf collapse. Science, 299(5612), 1560-1562.

Dowdeswell, J.A. and 10 others. 1997. The mass balance of circum-Arctic glaciers and recent climate change. Quat. Res., 48(1), 1-14.

Ermolin, E., H. De Angelis and P. Skvarca. 2002. Mapping of permafrost on Vega Island, Antarctic Peninsula, using satellite images and aerial photography. Ann. Glaciol., 34, 184-188.

Jamieson, A.W. and A.C. Wager. 1983. Ice, water and energy balances of Spartan Glacier, Alexander Island. Br. Antarct. Surv. Bull., 52, 155-186.

Jansson, P. 1999. Effect of uncertainties in measured variables on the calculated mass balance of Storglaciären. Geogr. Ann., 81A(4), 633-642.

King, J.C. 1994. Recent climate variability in the vicinity of the Antarctic Peninsula. Int. J. Climatol., 14(4), 357-369.

Mayo, L. R., M. F. Meier and W. V. Tangborn. 1972. A system to combine stratigraphic and annual mass-balance systems: a contribution to the International Hydrological Decade. J. Glaciol., 11(61), 3-14.

Orheim, O. and L.S. Govorukha. 1982. Present-day glaciation in the South Shetland Islands. Ann. Glaciol., 3, 233-238.

Østrem, G. and M. Brugman. 1991. Glacier mass-balance measurements. A manual for field and office work. Saskatoon, Sask., Environment Canada. National Hydrology Research Institute. (NHRI Science Report 4.)

Rott, H., P. Skvarca and T. Nagler. 1996. Rapid collapse of northern Larsen Ice Shelf, Antarctica. Science, 271(5250), 788-792.

Scambos, T. A., C. Hulbe, M. Fahnestock and J. Bohlander. 2000. The link between climate warming and break-up of ice shelves in the Antarctic Peninsula. J. Glaciol., 46(154), 516-530.

Schwerdtfeger, W. 1984. Weather and climate of the Antarctic. Amsterdam, Elsevier. (Developments in Atmospheric Science 15.)

Skvarca, P. and H. De Angelis. 2003. Impact assessment of regional climate warming on glaciers and ice shelves of the northeastern Antarctic Peninsula. In Domack, E. W., A. Burnett, A. Leventer, P. Conley, M. Kirby and R. Bindschadler, eds. Antarctic Peninsula climate variability: a historical and paleoenvironmental perspective. Washington, DC, American Geophysical Union, 69-78. (Antarctic Research Series 79.)

Skvarca, P., H. Rott and T. Nagler. 1995. Satellite imagery, a base line for glacier variation study on James Ross Island, Antarctica. Ann. Glaciol., 21, 291-296.

Skvarca, P., W. Rack, H. Rott and T. Ibarzábal y Donángelo. 1998. Evidence of recent climatic warming on the eastern Antarctic Peninsula. Ann. Glaciol., 27, 628-632.

Skvarca, P., W. Rack, H. Rott and T. Ibarzábal y Donángelo. 1999. Climatic trend and the retreat and disintegration of ice shelves on the Antarctic Peninsula: an overview. Polar Res., 18(2), 151-157.

Smith, A.M., D. G. Vaughan, C.S.M. Doake and A. C. Johnson. 1998. Surface lowering of the ice ramp at Rothera Point, Antarctic Peninsula, in response to regional climate change. Ann. Glaciol., 27, 113-118.

Vaughan, D.G. and C.S.M. Doake. 1996. Recent atmospheric warming and retreat of ice shelves on the Antarctic Peninsula. Nature, 379(6563), 328-331.

Wager, A.C. and A.W. Jamieson. 1983. Glaciological characteristics of Spartan Glacier, Alexander Island. Br. Antarct. Surv. Bull., 52, 221-228.

Weller, G. 1998. Regional impacts of climate change in the Arctic and Antarctic. Ann. Glaciol., 27, 543-552. 